\title{
Consumers' Willingness to Consume Cassava Leaves as a Leafy Vegetable in the Kumasi Metropolis, Ghana
}

\author{
Fred NimoH $^{\mathrm{a}}$, Godfred O. Asare ${ }^{\mathrm{a}}$, Ismael Twumasi ${ }^{\mathrm{a}}$, And Richmond AnAman ${ }^{\mathrm{a}}$ \\ ${ }^{\text {a }}$ Department of Agricultural Economics, Agribusiness and Extension, KNUST, Kumasi, Ghana \\ ${ }^{*}$ Corresponding author \\ frediemoh@yahoo.com
}

Received: 27 July 2017; Published online: 18 October 2018

\begin{abstract}
This study employs the logit model to assess the determinants of consumers' willingness to consume cassava leaves as a leafy vegetable in the Kumasi Metropolis of Ghana. A multistage sampling technique was used to select 180 respondents for the study. The study found that majority (76\%) of the respondents had no knowledge of the nutritional value of cassava leaves, though they had consumed the product before. The empirical results showed that socioeconomic characteristics of respondents such as age, sex, household size and monthly income, as well as their perceptions on the attributes and use of cassava leaves as food have significant influence on willingness to consume cassava leaves as a leafy vegetable. There is the need to provide information on the nutritional benefits of cassava leaves to facilitate decision-making on its utilisation/consumption. Programmes aimed at promoting the consumption of cassava leaves should consider the significant variables that have influence on the consumption of the product.
\end{abstract}

Keywords: Cassava leaves; Willingness to consume; Perception; Logit regression; Kumasi-Ghana

\section{Introduction}

Cassava is one of the most important staple food crops widely cultivated in the lowland humid tropics. It plays a major role in alleviating African food crises because of its efficient production for energy year round, availability, tolerance to extreme conditions and suitability to the farming and food systems in Africa (Scott, Rosegrant, \& Ringler, 2000). The world's total cassava utilization has been projected to 275 million tons by 2020 (Westby, 2002).

Cassava is grown nearly in every African country located between latitude $30^{\circ} \mathrm{C}$ north and south of the equator (Okigbo, 1980). The crop is Africa's second most important food staple in terms of per capita calories consumed (FAO, 2005). Africa contributes about half of the world's production of cassava; Nigeria leads with
$19 \%$ of global market share and Ghana is the third largest producer of cassava in Africa after Nigeria and the Democratic Republic of Congo (FAO, 2009). Cassava production in Ghana has grown steadily from $8,107,000 \mathrm{Mt}$ in 2000 to $13,504,000 \mathrm{Mt}$ in 2010 , and it is estimated to exceed $15,000,000 \mathrm{Mt}$ in 2015 .

Since its introduction to Africa, cassava has become one of the most important crops in Africa. It is an important source of dietary energy for over 600 million people in developing countries within the tropics and sub-tropics (Scott et al., 2000). It is currently grown as a subsistence crop, cash crop, for animal feed and as an industrial raw material for starch extraction or alcohol production. The young shoots (stems, leaves and petioles) of cassava are edible and widely used as food in Africa (Lancaster \& Brooks, 1983). The tuber has a number of uses in Ghana such as pro- 
cessing into gari, dough, tapioca, cassava flour and starch. In addition, the fresh tuber may be boiled and eaten as "ampesi" or pounded into a paste $(f u f u)$ and eaten with soup. Cassava leaves are also consumed to varying degrees in the cassava growing regions of Africa and constitute a major component of the diet in some countries (Bokanga, 1994).

Cassava leaves, as indigenous leaves, are classified as part of leafy vegetables. Cassava leaves are good source of proteins, vitamins and minerals (Gomez \& Noma, 1986). Cassava leaves are either served as part of a sauce or as cooked green vegetables, but their role in the diet is very different from that of the roots (Bokanga, 1994). The cassava leaf meal has been included in schools in basic food packs distributed to families among low income population (Motta, Fukuda, \& Costa, 1994). Moreover, cassava leaves have been found to have high nutrient value which can effectively boost the nutrition for animal production when preserved as hay, thereby assisting in formulating and processing of simple adoptable and low cost feed resource strategy during dry season when there is scarcity of forage (Wanapat, Puramongkon, \& Siphuak, 2000). However the utilisation of cassava leaves for human consumption is fairly low to other vegetables (Keller, 2004).

Ghana has the potential to develop a more attractive and independent economy by taking interests in the kind of crops cultivated and consumed, especially those vegetables produced for local consumption and export for foreign income. Vegetables are important sources of vitamins and minerals for human diet. Approximately 1.7 million $(2.8 \%)$ of deaths worldwide are attributable to low fruit and vegetable consumption (World Health Organization, 2003). FAO/WHO report on diet nutrition and prevention of diseases recommends a minimum daily intake of $200 \mathrm{~g}$ of vegetables or about $73 \mathrm{~kg} /$ year $/$ person. Unfortunately, priority has been based mostly on few types of vegetables such as spinach, amaranths, okra, nightshade eggplant and cowpea leaves (Weinberger, 2004), which are sometimes scarce and relatively expensive compared to cassava leaves. Many consumers underestimate the benefits of cassava leaves; they consider them as waste or animal feed. Also, the forgone benefits to farmers as income in periods of scarcity of conventional leafy vegetables such as "Kontomire" have contributed to their economic implications. The negative perception about cassava leaves can affect the consumption of the leaves. A positive perception of any commodity implies an encouraging approach to consumption of such commodity (Padberg, Riston, \& Albisu, 1997). Furthermore, the constraints associated with the consumption of any product determine the rate of intake of such commodity. Assessing consumers' perception and their willingness to consume cassava leaves as a leafy vegetable will help provide information and opportunity for food processors, farmers and other stakeholders along the commodity chain to boost the food industry and the economy at large.

\section{Materials and Methods}

\subsection{Conceptual framework and empirical model specification of the study}

The willingness of an individual to consume or not to consume a product can be explained as a distinct set of variables, regarding the choice of model. For this study, the dichotomous dependent variable, willingness to consume or not to consume, was used. According to Greene (2008), linear methods are inappropriate for dichotomous choices since they can lead to heteroscedastic variances. This problem is typically remedied by using maximum likelihood estimation. When heteroscedasticity is observed in likelihood estimation, such models require more general estimation (Wooldridge, 2002). However, such models are not often used, since logit and probit models with flexible functional forms in the independent variables tend to work well.

It is generally assumed that consumers maximize their utility subject to a budget constraint, and will therefore choose the option among a bundle of goods that gives them the highest utility. In considering the consumption of cassava leaves, consumers therefore expect their utility for consumption of cassava leaves as a leafy vegetable (assuming a monotonic relationship

\begin{tabular}{l|l|l|l} 
IJFS & October 2018 & Volume 7 & pages 38-50
\end{tabular} 
between utility and benefits) to be higher than the other alternative leafy vegetables. According to Greene (2003), random utility models address these types of individual choice situations. A common specification is the linear random utility model.

Suppose an individual consumer's utility after consuming the new leafy vegetable for a given vector of socioeconomic characteristics, perception and product attributes $(\mathrm{Z})$ is denoted by $U_{r e}(\mathrm{Z})$ and the utility without willingness to consume by $U N_{r e}(\mathrm{Z})$. The willingness to consume cassava leaves as a leafy vegetable or not can be defined as a linear relationship.

$$
\begin{aligned}
U_{W T C} & =Z \beta_{W T C}+\varepsilon_{W T C} \\
Y_{N W T C} & =Z \beta_{N W T C}+\varepsilon_{N W T C}
\end{aligned}
$$

In this case $\beta_{W T C}, \beta_{N W T C}$ and $\varepsilon_{W T C}, \varepsilon_{N W T C}$ are response coefficient and random consumption associated with willingness to consume and nonwillingness to consume respectively. Assuming that the qualitative variable $\mathrm{Y}_{N W T C}$ indexes the consumption, then it will take a value of one if the consumer is willing to consume cassava leaves as leafy vegetable and zero if otherwise. The probability that a consumer is willing to consume cassava leaves as a leafy vegetable could be expressed as a function of $\mathrm{Z}$ as follows:

$$
\begin{aligned}
& p(y=1)=p\left(U_{W T C}>U_{N W T C}\right) \\
& p\left(Z \beta_{W T C}+\varepsilon_{W T C}>Z \beta_{N W T C}+\varepsilon_{N W T C}\right) \\
& p\left[Z\left(\beta_{W T C}-\beta_{N W T C}\right)>\varepsilon_{N W T C}-\varepsilon_{W T C}\right] \\
& p(Z \beta>\varepsilon)=F(Z \beta)
\end{aligned}
$$

Where $P$ is a probability function, $\varepsilon=\varepsilon_{N W T C}-$ $\varepsilon_{W T C}$ is a random consumption term, $\beta=\beta_{W T C}$ - $\beta_{N W T C}$, a vector of unknown parameters which can be interpreted as net influence of the vector of independent variables on willingness to consume cassava leaves as leafy vegetable, and $F(\mathrm{Z}$ $\beta)$ is the cumulative distribution function for $\varepsilon$ evaluated at $\mathrm{Z} \beta$. The exact distribution of $F$ depends on the distribution of random term $\varepsilon$. The model arises from assuming a normal distribution, and a logit model arises from assuming a logistic distribution. Under the standard assumptions about the error term, there is no a-priori reason to prefer probit to logit estimation (Greene, 2003). Accordingly, in most applications, it seems not to make much difference. Considering all these aspects, a logit model was developed to study the factors affecting willingness to consume cassava leaves as a leafy vegetable in the Kumasi Metropolis.

According to the logit model, the probability of an individual's willingness to consume cassava leaves as a leafy vegetable - $(W T C)$ given socioeconomic characteristics, perception variables and product attributes $(Z)$ is, $P(W T C(Z)$ )and can be specified as:

$$
P[W T C(Z)]=\frac{e^{Z \beta+\varepsilon}}{1+e^{Z \beta+\varepsilon}}
$$

Where $\mathrm{a}<\mathrm{Z} \beta<\mathrm{a}$

The probability of not willing to consume cassava leaves as leafy vegetable is therefore:

$$
\begin{aligned}
P[N W T C] & =1-P[W T C(Z)] \\
& =1-\frac{e^{Z \beta+\varepsilon}}{1+e^{Z \beta+\varepsilon}} \\
& =\frac{1}{1+e^{Z \beta+\varepsilon}}
\end{aligned}
$$

The relative odds of willing to consume versus not willing to consume are given by:

$$
\begin{aligned}
\frac{P(W T C(Z))}{P(N W T C(Z))} & =\frac{e^{Z \beta+\varepsilon} 1+e^{Z \beta+\varepsilon}}{1+e^{Z \beta+\varepsilon}} \\
& =e^{Z \beta+\varepsilon}
\end{aligned}
$$

By taking the logarithms of both sides,

$$
\operatorname{In}\left[\frac{P(W T C / Z)}{P(N W T C / Z)}\right]=Z \beta+\varepsilon
$$

The maximum likelihood approach can be used to estimate the above equation. The factors influencing the willingness to consume cassava leaves as a leafy vegetable in the Kumasi metropolis can be specified empirically as indi- 
cated in (12) as;

$$
\begin{aligned}
& W T C_{i j}=\beta_{o}+\beta_{1} S_{e x}+\beta_{3} H D_{s i z e_{i j}} \\
& +\beta_{4} N o . \_y r s \_i n \_s c h h_{i j}+\beta_{5} M_{-} i n c_{i j} \\
& +\beta 6 \text { Sweet }_{i j}+\beta_{7} \text { Bitter }_{i j} \\
& +\beta_{8} P_{-} \text {essentialmin }{ }_{i j}+\beta_{9} \text { Animal }_{-} \text {feed }_{i j} \\
& +\beta_{1} \text { 0eaten_as_food } \text { ij }_{1}+\beta_{1} 1 \text { good_substitute } \\
& +\beta_{1} 2 \text { poisonous_comp } p_{i j}+\beta_{1} 3 \text { Affect_HHealth }{ }_{i j} \\
& +\beta_{1} 4 U \text { sed_in_household }{ }_{i j} \\
& +\beta_{1} 5 \text { Affects_tubber_form } \text { f }_{i j} \\
& +\beta_{1} \text { 6Sold_on_market }{ }_{i j}+\beta_{1} 7 \text { Saves_cost } t_{i j} \\
& +\beta_{1} 8 \text { For_poor_people } e_{i j}+\beta_{1} 9 \text { Aroma }_{i j} \beta_{i j} \\
& + \text { beta }_{2} 0 \text { Texture }_{i j}+\beta_{2} 1 \text { Gen_appearance }_{i j}
\end{aligned}
$$

Where $W T C$ denotes willingness to consume cassava leaves as a leafy vegetable $(W T C=1$, if consumer is willing to consume cassava leaves as a leafy vegetable, $N W T C=0$, if otherwise). Sex, denotes gender of the consumer $(1=$ male and $0=$ female). Age, represents the age of the consumer (years). Hd_size, denotes household size (number of people in the household). No._yrs_in_sch, denotes the number of years spent in school. $\quad M_{-}$inc denotes consumer's monthly income (GHC). Sweet represents if cassava leaves are sweet to taste. Bitter represents if cassava leaves are bitter to taste. P_essential min. denotes if cassava leaves provide essential nutrients when eaten as leafy vegetable. Animal feed represents if cassava leaves should be used as animal feed. Eaten as food represents if cassava leaves should be eaten as human food (leafy vegetable). Good substitute represents if cassava leaves are good substitute to other leafy vegetables. Poisonous comp. denotes if cassava leaves contain poisonous components like cyanide. Affect HHealth denotes if cassava leaves could affect human health when consumed as leafy vegetable. Used in household represents if cassava leaves should be used in households. Affects_tuber_form denotes if cassava leaves affects tuber formation when plucked and consumed. Sold on market represents if cassava leaves are considered as useful good and therefore should be sold on the market. Saves cost represents if cassava leaves could save cost if consumed as leafy vegetable. For poor people represents if cassava leaves are mostly for poor people. Aroma represents if the aroma of cassava leaves makes it unsuitable to be consumed as a leafy vegetable. Texture represents if the texture (chewiness) of cassava leaves makes it unsuitable to be consumed as a leafy vegetable. Gen_appearance denotes if the general appearance of cassava leaves makes it unsuitable to be consumed as a leafy vegetable and $\beta_{1}, \beta_{2}$, $\beta_{3}, \ldots, \beta_{2} 1$ represent the coefficients of the variables. $\varepsilon_{i}$ denotes error term capturing all factors unknown to the researcher.

\subsection{Statement of hypotheses}

Hypothesis 1: Socio-economic variables such as age, number of years of formal education, household size, and monthly income have influence on willingness to consume cassava leaves as leafy vegetable in the Kumasi Metropolis.

Hypothesis 2: Perception on the product's attributes such as aroma, texture and general appearance consumption of cassava leaves have influence on willingness to consume cassava leaves as a leafy vegetable in the Kumasi Metropolis.

\subsection{Data Collection and Sampling method}

A multistage sampling technique was employed for this study. This was used to ensure fair representation within the Metropolis. The stratified random sampling technique was used to select communities from the metropolis since they were clustered into low, middle and high income groups (Table 1). The simple random sampling technique was also used to select communities within the residential income class of communities. In all, a total of 180 respondents from 12 randomly selected communities out of the 78 in the Kumasi Metropolis were considered in the survey for this study; 4 communities from low income category, 4 communities from middle income category and 4 communities from high income category. The systematic random sampling technique was used to select fifteen respondents each from the sampled communities (Table 2). The face-to-face interview technique was employed using a structured questionnaire. This was to provide the opportunity to explain ques- 
tions which were difficult to answer, to obtain the exact information needed for the study, and also to afford the interviewer the opportunity to educate the respondents. The study population was targeted at all consumers of leafy vegetables and assessed based on income groups of the respondents. One reason for using income groups as a basis is that consumption is a function of income (Edgmand, 1987).

\section{Results and Discussions}

\subsection{Socio-economic characteristics of respondents in the Kumasi Metropolis}

Majority of the respondents $(60 \%)$ interviewed were females. The average respondents' age interviewed was 37 years (Table 3). The average household size of the respondents was 4 persons. The average number of years of education among the respondents was 13.9 years representing secondary education. The average respondents' monthly income was GHC1,191.22.

\subsection{Consumers' awareness of the nutritional status of cassava leaves}

Amongst the total number of respondents interviewed, 43 representing $23.9 \%$ had knowledge of the nutritional status of cassava leaves whereas 137 representing 76.1 percent did not have any knowledge of the nutritional status of the product as depicted in the Figure 1.

\subsection{Utilization of cassava leaves by Respondents}

About $92 \%$ of the respondents interviewed had consumed cassava leaves before as food (either as vegetable salad, stew or for soup) in the past, $5 \%$ as food and as medicine, and about 3\% had also consumed cassava leaves as food, as medicine, used as animal feed and as farm material (Figure 2).

\subsection{Consumers' perception on consumption of cassava leaves as a leafy vegetable}

The perception of a product determines the rate of consumption of a particular commodity as indicated by Padberg et al. (1997) that consumers' attitude towards a product depend heavily on their perception about the product. There is therefore a link between attitude and perception. Consumers' willingness to consume a product is influenced largely by their attitudes and determines their choice of decision making (Alvensleben \& Meier, 1989). Consumers' opinions were sought on the nutritional, health and economic concepts on consumption of cassava leaves as leafy vegetable in the Kumasi Metropolis as presented in Table 4.

The study found an overall perception index as 1.98, implying a neutral idea about cassava leaves as a leafy vegetable and thus, indicates that majority of respondents did not know about the nutritional, health and economic benefits of cassava leaves as a leafy vegetable in the Kumasi Metropolis. The product attributes on assessment also provides a significant influence on whether respondents will consume cassava leaves as a leafy vegetable or not. This affirms the statements by Ragaert, Verbeke, Devlieghere, and Debevere (2004) that product attributes play a significant contribution on consumption of a particular commodity.

$$
\begin{aligned}
T C P & =\frac{N p+H p+E p+A p}{4} \\
& =\sum\left(\frac{1.67+2.26+1.78+2.22}{4}\right) \\
& =1.98
\end{aligned}
$$

Where, TCP is the total perception index, $N p$ is Nutritional perception; HP is Health perception; $E p$ is Economis perception and $A p$ is Attribute perception. 


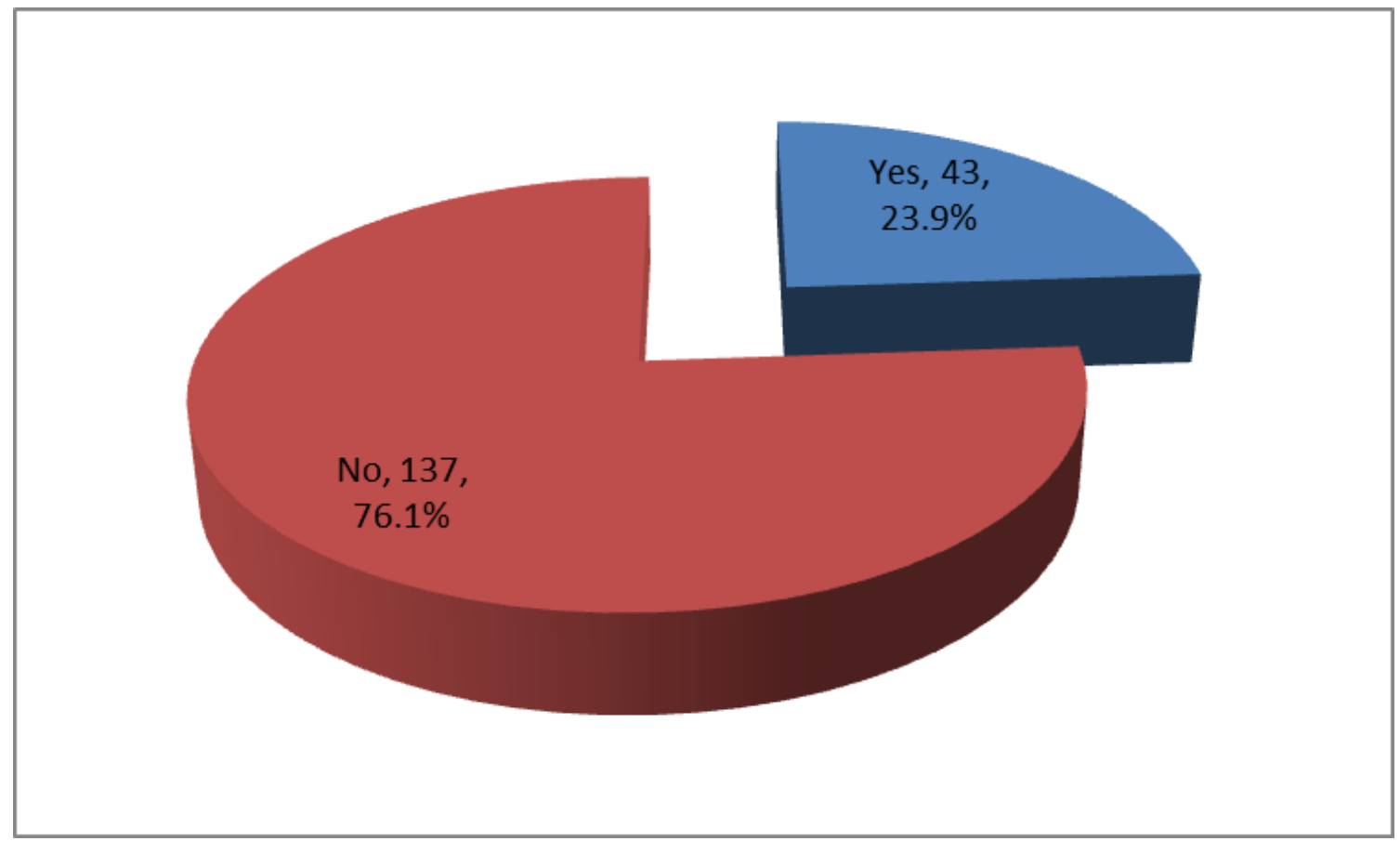

Figure 1: Consumers' awareness of the nutritional status of cassava leaves

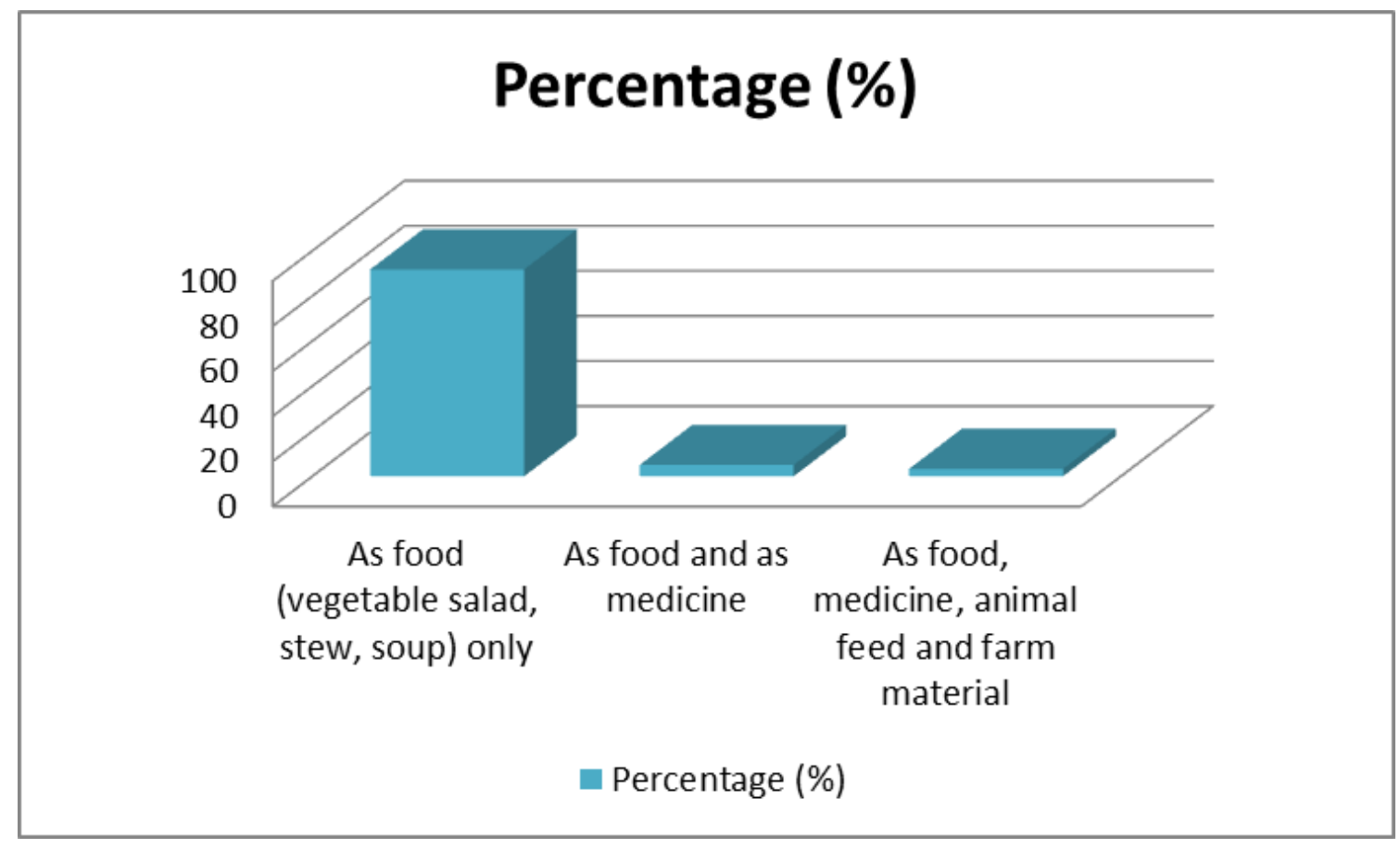

Figure 2: Utilization of cassava leaves by Respondents 
Table 1: Residential Income Classes of Communities in the Kumasi Metropolis

\begin{tabular}{ll}
\hline \multirow{2}{*}{ High Income } & $\begin{array}{l}\text { Dadiesoaba, Asokwa, West Ayigya, Mbrom, Adiebeba, Adiembra, Ahodwo, Danyame, } \\
\text { Odeneho Kwadaso, Aketego, Bomso, Bompe, Ridge, Nhyiaso, Extension, Parakuo Estate, } \\
\text { Daban New Site, New Amakom Extension, Asokwa Residential Area }\end{array}$ \\
\hline \multirow{3}{*}{ Middle Income } & $\begin{array}{l}\text { Asafo, Amakom, Airport, Bantama, Dichemso, Aprade, New Tafo, Asebi, Anyinam, Kuwait, } \\
\text { Atonsu, New Atonsu, Gyenyase, New Agogo, Adoato, Kyirapatre Estate, Bohyen, Adumanu, } \\
\text { Adumanu Extension, Asanti Newtown, Apiri, North Suntreso, Kotei, South Suntreso, } \\
\text { Boadi West Patase, Ohwimase, Kwadaso Estate, Santase Odumase Extension, Patase, Kentinkrono }\end{array}$ \\
\hline \multirow{2}{*}{ Low Income } & $\begin{array}{l}\text { Apatrapa, Dompoase, Aboabo, Moshie Zongo, Dichemso, Old Tafo, Ayigya Zongo, } \\
\text { Dakwadwom, Sawaba, Yalwa, Daban, Kaase, Sokoban, Nsenee, Ahinsan, Anwomaso, Gyinyase, } \\
\text { Adukrom, Asewase, Buobai, Nima, Pakuso, Abrepo, Sokoban, Amanfrom, Yenyawso, Buokrom, Ayeduase }\end{array}$ \\
\hline
\end{tabular}

Source: KMA, 2007

Table 2: Sampled communities within the Residential income class of communities

\begin{tabular}{lll}
\hline \multirow{2}{*}{ INCOME CATEGORY } & RESIDENTIAL COMMUNITIES & NUMBER OF HOUSEHOLDS \\
\hline \multirow{3}{*}{ HIGH INCOME } & Bomso & 15 \\
& Ahodwo & 15 \\
& Ridge & 15 \\
& Asokwa residential area & 15 \\
MIDDLE INCOME & Asafo & 15 \\
& North Suntreso & 15 \\
& Boadi & 15 \\
\multirow{2}{*}{ LOW INCOME } & Amakom & 15 \\
& Ayigya Zongo & 15 \\
& Aboabo & 15 \\
& Anwamaso & 15 \\
& Old Tafo & 15 \\
\hline
\end{tabular}

Source: Field survey, 2016

\subsection{Estimation of factors affecting consumers' willingness to consume cassava leaves as a leafy vegetable in the Kumasi Metropolis}

The study found a significant difference in the socioeconomic characteristics of the respondents and their perceptions with regards to the willingness to consume cassava leaves as leafy vegetable or not (Table 5). Based on the empirical results from the logit model (Table 6), age was found to be significant at $5 \%$ on consumers' willingness to consume cassava leaves as leafy vegetable. The direction of the variable was positive, meaning among the respondents interviewed those of older ages tend to consume cassava leaves as leafy vegetable. This can be explained that a unit change in the age of a consumer will increase willing- ness to consume cassava leaves by $0.39 \%$. This is partly geared to the increase in knowledge of the benefits of fruits and vegetables (Elfhag, Tholin, \& Rasmussen, 2008). In children and adolescents, consumption tends to decrease with age (Rasmussen et al., 2006). Sex of respondents was positive and significant at $10 \%$. This finding agrees with Rasmussen et al. (2006). A unit change in male consumers will increase willingness to consume cassava leaves as leafy vegetable by $3.71 \%$. Also respondents' monthly income was found to have a negative influence on willingness to consume cassava leaves as leafy vegetable at $10 \%$ significance level. This implies that, a unit change in monthly income of consumers in the Kumasi Metropolis will decrease willingness to consume cassava leaves as leafy vegetable by $6.2 \%$.

The perception variable "cassava leaves are 
Consumers' willingness to consume cassava leaves 45

Table 3: Socio-economic characteristics of respondents

\begin{tabular}{|c|c|c|c|c|}
\hline Variable & \multicolumn{2}{|l|}{ Category } & $\begin{array}{l}\text { Frequency } \\
(\%)\end{array}$ & Percentage \\
\hline \multirow{2}{*}{ Gender } & \multicolumn{2}{|l|}{ Male } & 72 & 40 \\
\hline & \multicolumn{2}{|l|}{ Female } & 108 & 60 \\
\hline \multirow{3}{*}{ Marital status } & \multicolumn{2}{|l|}{ Married } & 88 & 48.9 \\
\hline & \multicolumn{2}{|c|}{ Single } & 71 & 39.4 \\
\hline & \multicolumn{2}{|c|}{ Divorced/ Separated } & 21 & 11.7 \\
\hline \multirow{5}{*}{ Education level } & \multicolumn{2}{|c|}{ Basic } & 41 & 22.8 \\
\hline & \multicolumn{2}{|l|}{ Secondary } & 58 & 32.2 \\
\hline & \multicolumn{2}{|l|}{ Tertiary } & 51 & 28.3 \\
\hline & \multicolumn{2}{|l|}{ Vocational } & 21 & 11.7 \\
\hline & \multicolumn{2}{|l|}{ Illiterate } & 9 & 5.0 \\
\hline \multirow{4}{*}{ Tribe } & \multicolumn{2}{|l|}{ Akan } & 141 & 78.3 \\
\hline & \multicolumn{2}{|l|}{$\mathrm{Ga}$} & 8 & 4.4 \\
\hline & \multicolumn{2}{|l|}{ Ewe } & 10 & 5.6 \\
\hline & \multicolumn{2}{|l|}{ Northern } & 21 & 11.7 \\
\hline Continuous variables & Minimum & Maximum & Mean & Std. deviation \\
\hline Age (years) & 18 & 72 & 36.73 & 13.00 \\
\hline Household size (in persons) & 1 & 9 & 4.36 & 1.55 \\
\hline Number of years in school & 0 & 23 & 13.97 & 5.18 \\
\hline Monthly Income (GHC) & 0.00 & 7000.00 & 1191.22 & 1203.20 \\
\hline
\end{tabular}

Source: Field Survey, 2016

sweet" had a positive influence on consumption of cassava leaves and was significant at $1 \%$. This result is consistent with the finding of Kamga, Kouame, Tchindjang, Chagomoka, and Drescher (2013). This means that, a unit change in the perception statement variable "cassava leaves are sweet" will increase willingness to consume cassava leaves as leafy vegetable by $10.55 \%$. Also, the perception variable "Cassava leaves are bitter" was negative and was found to significantly affect consumption of cassava leaves at $1 \%$ level. This implies that, a unit change in the perception statement "Cassava leaves are bitter" will decrease willingness to consume cassava leaves as leafy vegetable by $12.2 \%$. The perception variable "Cassava leaves should be used as animal feed" was negative and was found to significantly affect consumption of cassava leaves at $5 \%$ level. This indicates that, a unit change in the perception statement "Cassava leaves should be used as animal feed" will decrease willingness to consume cassava leaves as leafy vegetable by $4.58 \%$. Moreover, the perception that "cassava leaves should be eaten as food" had a positive and a $1 \%$ significant influence on consumption of cassava as a leafy vegetable. A change in the unit of the perception variable "Cassava leaves should be eaten as food" will increase willingness to consume cassava leaves as leafy vegetable by $6.84 \%$. "Cassava leaves are good substitute" was positive and significant at $5 \%$. This connotes that a unit change in the perception variable "Cassava leaves are good substitute" will increase willingness to consume cassava leaves as leafy vegetable by $5.85 \%$. The perception variable "Cassava leaves are useful and therefore should be sold on the market" was found to be positive and significant at $10 \%$. This implies that a unit change in the perception variable "Cassava leaves are useful and therefore should be sold on the market" will increase willingness to consume cassava leaves as leafy vegetable by $2.66 \%$. Also "Aroma and General appearance" were negative and have significant influence on consumption of cassava leaves at $1 \%$ and 5\% respectively. This implies that a unit change in the cooked cassava leaves aroma will 
46 | Nimoh et al.

Table 4: Consumers' perception on consumption of cassava leaves as a leafy vegetable

\begin{tabular}{|c|c|c|c|c|}
\hline Nutritional perception statements on cassava leaves & $\begin{array}{r}\text { Agree } \\
(1)\end{array}$ & $\begin{array}{r}\text { Neutral } \\
(2)\end{array}$ & $\begin{array}{r}\text { Disagree } \\
(3)\end{array}$ & $\begin{array}{l}\text { Mean } \\
\text { Score }\end{array}$ \\
\hline Cassava leaves are sweet & 14 & 120 & 46 & 2.18 \\
\hline Cassava leaves are bitter & 48 & 119 & 13 & 1.81 \\
\hline Cassava leaves provide some essential nutrients & 57 & 123 & 0 & 1.68 \\
\hline Cassava leaves should be used as animal feed & 156 & 1 & 23 & 1.26 \\
\hline Cassava leaves should be eaten as food & 132 & 1 & 47 & 1.53 \\
\hline $\begin{array}{l}\text { Cassava leaves are good substitute for other known leafy } \\
\text { vegetables such as Spinach, lettuce }\end{array}$ & 127 & 11 & 42 & 1.53 \\
\hline Nutritional Perception index & & & & 1.67 \\
\hline Health perception statement on cassava leaves & $\begin{array}{r}\text { Agree } \\
(1)\end{array}$ & $\begin{array}{r}\text { Neutral } \\
(2)\end{array}$ & $\begin{array}{r}\text { Disagree } \\
(3)\end{array}$ & $\begin{array}{l}\text { Mean } \\
\text { Score }\end{array}$ \\
\hline Cassava leaves contains poisonous components like cyanide & 52 & 64 & 64 & 2.07 \\
\hline Cassava leaves could affect human health when consumed & 38 & 22 & 120 & 2.46 \\
\hline Health Perception index & & & & 2.27 \\
\hline Economic perception statements & $\begin{array}{r}\text { Agree } \\
(1)\end{array}$ & $\begin{array}{r}\text { Neutral } \\
(2)\end{array}$ & $\begin{array}{r}\text { Disagree } \\
(3)\end{array}$ & $\begin{array}{l}\text { Mean } \\
\text { Score }\end{array}$ \\
\hline Cassava leaves should be used in households for cooking & 130 & 2 & 48 & 1.54 \\
\hline Cassava leaves affect tuber formation if plucked and consumed & 161 & 17 & 2 & 1.12 \\
\hline Cassava leaves are useful and therefore should be sold on the market & 35 & 1 & 144 & 2.61 \\
\hline ve cost if consumed as leafy vegetable & 126 & 19 & 35 & 1.49 \\
\hline Cassava leaves are mostly for poor people & 43 & 66 & 71 & 2.16 \\
\hline Economic Perception index & & & & 1.78 \\
\hline Attribute statements on cassava leaves & $\begin{array}{r}\text { Agree } \\
(1)\end{array}$ & $\begin{array}{r}\text { Neutral } \\
(2)\end{array}$ & $\begin{array}{r}\text { Disagree } \\
(3)\end{array}$ & $\begin{array}{l}\text { Mean } \\
\text { Score }\end{array}$ \\
\hline Aroma & 6 & 116 & 58 & 2.29 \\
\hline Color (green) & 0 & 57 & 123 & 2.68 \\
\hline Texture & 42 & 113 & 25 & 1.91 \\
\hline General appearance & 81 & 17 & 82 & 2.01 \\
\hline Attributes index & & & & 2.22 \\
\hline
\end{tabular}

Source: Field Survey, 2016

decrease willingness to consume cassava leaves as leafy vegetable by $6.32 \%$ and $4.76 \%$. This result is in line with Padberg et al. (1997), who stated that consumers' attitude towards a product depends heavily on their perception of the product. It was again found that, the product attribute "Texture" had positive influence on willingness to consume cassava leaves as leafy vegetable at $1 \%$ significance level. This indicates that a unit change in texture of cassava leaves will increase consumers' willingness to consume cassava leaves as leafy vegetable by $10.63 \%$. This result is consistent with the finding of Kamga et al. (2013) that consumers' preferences of any particular commodity depend highly on the attributes of the product.

\subsection{Consumers' constraints on utilization of cassava leaves as a leafy vegetable in the Kumasi Metropolis}

Table 7 shows the constraints to consumption of cassava leaves in the study area. The study found "presence of other leafy vegetables" as the major limitation that hinders the respondents from consuming cassava leaves as leafy vegetable. Consumers in the Kumasi Metropolis who did not eat cassava leaves as a leafy vegetable attributed the "presence of other leafy vegetables" as the major constraint. This is in line with the statements of Weinberger (2004) that priority has been based mostly on few types of vegetables 
Consumers' willingness to consume cassava leaves $\mid 47$

Table 5: Descriptive statistics of respondents in the Kumasi Metropolis

\begin{tabular}{lrrrr}
\hline Independent variable & NWTC & WTC & Mean difference & Significance \\
\hline Sex & 0.38 & 0.45 & 0.07 & $0.007^{* * *}$ \\
Age & 31.23 & 47.73 & 16.50 & $0.096^{*}$ \\
Hd_size & 3.98 & 5.13 & 1.15 & 0.110 \\
No._yrs_in_sch & 14.94 & 12.03 & -2.91 & $0.000^{* * *}$ \\
M_inc & 1043.08 & 1487.50 & 444.42 & $0.002^{* * *}$ \\
Sweet & 0.01 & 0.22 & 0.21 & $0.000^{* * *}$ \\
Bitter & 0.03 & 0.73 & 0.70 & $0.000^{* * *}$ \\
P_essential min. & 0.27 & 0.42 & 0.15 & $0.001^{* * *}$ \\
Animal feed & 0.94 & 0.72 & -0.23 & $0.000^{* * *}$ \\
Eaten as food & 0.63 & 0.95 & 0.33 & $0.000^{* * *}$ \\
Good substitute & 0.57 & 0.97 & 0.40 & $0.000^{* * *}$ \\
Poisonous comp. & 0.36 & 0.15 & -0.21 & $0.000^{* * *}$ \\
Affect HHealth & 0.30 & 0.03 & -2.27 & $0.000^{* * *}$ \\
Used in household & 0.61 & 0.95 & 0.34 & $0.000^{* * *}$ \\
Affect tuber_form. & 0.88 & 0.93 & 0.06 & $0.014^{* *}$ \\
Sold on market & 0.15 & 0.28 & 0.13 & $0.000^{* * *}$ \\
Saves cost & 0.58 & 0.93 & 0.35 & $0.000^{* * *}$ \\
For poor people & 0.24 & 0.23 & -0.01 & 0.805 \\
Aroma & 0.02 & 0.07 & 0.05 & $0.000^{* * *}$ \\
Texture & 0.02 & 0.67 & 0.65 & $0.000^{* * *}$ \\
Gen_appearance & 0.61 & 0.15 & -0.46 & $0.000^{* * *}$ \\
\hline
\end{tabular}

Source: Field Survey, 2016

***,**,* indicating significance at $1 \%, 5 \%, 10 \%$ respectively

such as spinach, amaranths, okra, nightshade eggplant and cowpea leaves which has caused some indigenous vegetables like cassava leaves to be extinct.

\section{Conclusion}

Based on the findings, it can be concluded that majority of consumers in the Kumasi Metropolis were not aware of the nutritional status of cassava leaves and this tended to inform their decision to accept and consume cassava leaves as a leafy vegetable. Respondents who were aware of the nutritional contents did not have a thorough knowledge of all the nutritional components and benefits. Most of the respondents in the Kumasi Metropolis agreed to consume cassava leaves as a leafy vegetable after being educated on its specific nutrients present. Therefore, awareness of the nutritional status informed consumers' willingness to consume cassava leaves as a leafy veg- etable. Respondents did not have a positive perception on consumption of cassava leaves as a leafy vegetable. Due to inadequate knowledge of the nutritional status of cassava leaves, majority of the respondents did not agree or were neutral on the nutritional, health and economic benefits of cassava leaves.

Negative perception on consumption had influence consumers' willingness to consume cassava leaves as a leafy vegetable. Factors such as sociodemographic characteristics (age, sex, household, monthly income) and product attributes (aroma, texture and general appearance) were found to determine consumers' willingness to consume cassava leaves as leafy vegetable in the Kumasi Metropolis. Moreover, the presence of other leafy vegetables in the study area was identified as affecting the consumption of cassava leaves.

Based on key findings, the study recommends that research, educational and health institutions should promote the consumption of cassava 
Table 6: Logit regression model on assessing consumers' willingness to consume cassava leaves as leafy vegetable in the Kumasi Metropolis

\begin{tabular}{|c|c|c|c|c|}
\hline WTC & Coefficient & Standard error & $\mathrm{dy} / \mathrm{dx}$ & P-value \\
\hline Sex & $2.2743^{*}$ & 1.3243 & 0.0371 & 0.0860 \\
\hline Age & $0.2425^{* *}$ & 0.1105 & 0.0039 & 0.0280 \\
\hline Household size & $0.6782^{* *}$ & 0.3268 & 0.0110 & 0.0380 \\
\hline Number of years in school & 0.0673 & 0.0944 & 0.0010 & 0.4760 \\
\hline Monthly income & $-0.0147^{*}$ & 0.0007 & -0.0000 & 0.0620 \\
\hline \multicolumn{5}{|l|}{ Perception variables } \\
\hline Cassava leaves are sweet & $6.4674^{* * *}$ & 1.5455 & 0.1055 & 0.0000 \\
\hline Cassava leaves are bitter & $-7.4814^{* * *}$ & 1.9811 & -0.1220 & 0.0000 \\
\hline Cassava leaves provide some essential nutrients & -1.3464 & 1.1876 & -0.0219 & 0.2570 \\
\hline Cassava leaves should be used as animal feed & $-2.8124^{* *}$ & 1.2005 & -0.0458 & 0.0190 \\
\hline Cassava leaves should be eaten as food & $-4.1952^{* * *}$ & 1.2848 & -0.0684 & 0.0010 \\
\hline Cassava leaves has a good substitute & $3.5895^{* *}$ & 1.7513 & 0.0585 & 0.0400 \\
\hline Cassava leaves contains poisonous components & 1.3895 & 1.4395 & 0.0226 & 0.3340 \\
\hline Cassava leaves could affect human health & 0.8460 & 1.8167 & 0.0138 & 0.6410 \\
\hline Cassava leaves should be used in households for cooking & 1.0881 & 1.3673 & 0.0177 & 0.4250 \\
\hline Cassava leaves affect tuber formation if plucked and consumed. & -0.3775 & 1.3637 & -0.0061 & 0.7820 \\
\hline Cassava leaves are useful and therefore should be sold on the market & $1.6329 *$ & 0.8852 & 0.0266 & 0.0650 \\
\hline Cassava leaves save cost if consumed as leafy vegetable & -2.4913 & 1.5899 & -0.0406 & 0.1170 \\
\hline Cassava leaves are mostly for poor people & -2.3271 & 1.4643 & -0.0379 & 0.1120 \\
\hline Aroma & $-3.8735^{* * *}$ & 1.4041 & -0.0632 & 0.0060 \\
\hline Texture & $6.5161^{* * *}$ & 1.5851 & 0.1063 & 0.0000 \\
\hline General Appearance & $-2.9215^{* *}$ & 1.4071 & -0.0476 & 0.0380 \\
\hline
\end{tabular}

$* * *, * *, *$ indicating significance at $1 \%, 5 \%, 10 \%$ respectively.

Source: Authors' calculations, 2016

Table 7: Consumers' constraints on utilization of cassava leaves as leafy vegetable in the Kumasi Metropolis

\begin{tabular}{|c|c|c|c|c|c|c|c|}
\hline Constraints & $\begin{array}{c}\text { Most serious } \\
\text { (1) }\end{array}$ & $\begin{array}{c}\text { More serious } \\
(2)\end{array}$ & $\begin{array}{l}\text { Moderate } \\
\quad(3)\end{array}$ & $\begin{array}{l}\text { Slightly serious } \\
\text { (4) }\end{array}$ & $\begin{array}{l}\text { Least } \\
(5)\end{array}$ & Mean score & Rank \\
\hline Presence of other leafy vegetables & 122 & 16 & 12 & 12 & 7 & 1.6154 & $\mathbf{1}^{S T}$ \\
\hline Unaware if consumable & 6 & 4 & 3 & 1 & 1 & 2.1333 & $\mathbf{2}^{N D}$ \\
\hline Toxic components & 9 & 7 & 3 & 5 & 2 & 2.3846 & $3^{R D}$ \\
\hline Product attributes & 8 & 36 & 15 & 11 & 11 & 2.7654 & $\mathbf{4}^{T H}$ \\
\hline Unaware of nutritional benefits & 5 & 25 & 24 & 17 & 8 & 2.9747 & $\mathbf{5}^{T H}$ \\
\hline No thorough education on consumption & 7 & 24 & 31 & 26 & 13 & 3.1386 & $\mathbf{6}^{T H}$ \\
\hline Time of cooking & 5 & 7 & 13 & 11 & 6 & 3.1429 & $\mathbf{7}^{T H}$ \\
\hline Not motivated & 3 & 9 & 9 & 9 & 10 & 3.3571 & $8^{T H}$ \\
\hline Not preferred by household & 2 & 10 & 10 & 13 & 13 & 3.5208 & $\mathbf{9}^{T H}$ \\
\hline Unavailability at market & 2 & 7 & 6 & 5 & 8 & 3.3571 & $10^{T H}$ \\
\hline Not consumed by parents & 4 & 7 & 21 & 22 & 18 & 3.5972 & $\mathbf{1 1} \mathbf{1}^{T H}$ \\
\hline Effect to tuber formation & 4 & 5 & 11 & 10 & 15 & 3.6000 & $12^{T H}$ \\
\hline Stigmatization & 2 & 10 & 10 & 12 & 24 & 3.7931 & $13^{T H}$ \\
\hline Dirty on sight & 0 & 3 & 4 & 8 & 14 & 3.5972 & $14^{T H}$ \\
\hline Perceived as animal feed & 0 & 1 & 2 & 5 & 7 & 4.2000 & $15^{T H}$ \\
\hline Pests infestation & 0 & 1 & 4 & 9 & 16 & 4.3333 & $16^{T H}$ \\
\hline
\end{tabular}


leaves as a leafy vegetable by providing thorough information which will make respondents aware of the nutritional benefits of cassava leaves. Educating consumers on the health benefits of cassava leaves would help re-orient their perception on consumption of cassava leaves as a leafy vegetable.

\section{References}

Alvensleben, R. v. \& Meier, T. (1989). The influence of origin and variety on consumer perception. In Workshop on measuring consumer perception of internal product quality 259 (pp. 151-162).

Bokanga, M. (1994). Processing of cassava leaves for human consumption. In International workshop on cassava safety 375 (pp. 203208).

Edgmand, M. R. (1987). Macroeconomics theory and policy. third edition (N. J. .-.-. U. Prentice-Hall Englewood Cliff, Ed.). Retrieved from https : / / www amazon . com/Macroeconomics-Theory-Michael-REdgmand/dp/0135429528

Elfhag, K., Tholin, S., \& Rasmussen, F. (2008). Consumption of fruit, vegetables, sweets and soft drinks are associated with psychological dimensions of eating behaviour in parents and their 12-year-old children. Public Health Nutrition, 11(9), 914-923. doi:10.1017/S1368980008002371

Gomez, G. \& Noma, A. T. (1986). The aminoacid-composition of cassava leaves, foliage, root tissues and whole-root chips. Nutrition Reports International, 33(4), 595-601.

Greene, W. H. (2003). Econometric analysis, 5th edition (P. Hall, Ed.). Retrieved from http: / / www . worldcat. org / title / econometricanalysis/oclc/50252029

Greene, W. H. (2008). Econometric analysis, 6th edition (P. Hall, Ed.). Retrieved from http:// www . scirp . org / (S(351jmbntvnsjt1aadkposzje))/reference/ ReferencesPapers . aspx ? ReferenceID = 1883856

Kamga, A., Kouame, C., Tchindjang, M., Chagomoka, T., \& Drescher, A. W. (2013). Environmental impacts from overuse of chemical fertilizers and pesticides amongst market gardening in bamenda, cameroon. 1, 6-19.

Keller, G. (2004). African nightshade, eggplant, spiderflower et al.-production and consumption of traditional vegetables in tanzania from the farmers point of view. Masterarbeit im wissenschaftlichen Studiengang Agrarwissenschaften an der GeorgAugust Universität Göttingen, Fakultät für Agrawissenschaft.

Lancaster, P. A. \& Brooks, J. E. (1983). Cassava leaves as human food. Economic Botany, 37(3), 331-348. doi:10.1007/BF02858890

Motta, J. S., Fukuda, W. G., \& Costa, Z. M. (1994). Farinha da folha de mandioca: uma alternativa como complemento alimentar. Mandioca em foco, 4 (1), 1-2.

Okigbo, B. N. (1980). Nutritional implications of projects giving high priority to the production of staples of low nutritive quality: the case for cassava (manihot esculenta, crantz) in the humid tropics of west africa. Food and Nutrition Bulletin, 2(4), 1-10.

Padberg, D. I., Riston, C., \& Albisu, L. M. (1997). Agro-food marketing cab international. (pp. 209-224). CABI Publishing, Oxford, UK.

Ragaert, P., Verbeke, W., Devlieghere, F., \& Debevere, J. (2004). Consumer perception and choice of minimally processed vegetables and packaged fruits. Food Quality and Preference, 15(3), 259-270. doi:10.1016/ S0950-3293(03)00066- 1

Rasmussen, M., Krolner, R., Klepp, K.-I., Lytle, L., Brug, J., Bere, E., \& Due, P. (2006). Determinants of fruit and vegetable consumption among children and adolescents: a review of the literature. part i: quantitative studies. International Journal of Behavioral Nutrition and Physical Activity, 3. doi:10.1186/1479-5868-3-22

Scott, G. J., Rosegrant, M. W., \& Ringler, C. (2000). Roots and tubers for the 21st century: trends, projections, and policy options. International Food Policy Research Institute (IFPRI) and International Potato Centre (CIP).

Wanapat, M., Puramongkon, T., \& Siphuak, W. (2000). Feeding of cassava hay for lactating 
dairy cows. Asian-australasian Journal of Animal Sciences, 13(4), 478-482. doi:10. 5713/ajas.2000.478

Weinberger, K. (2004). Indigenous vegetables in tanzania: significance and prospects. AVRDC-WorldVegetableCenter.

Westby, A. (2002). Cassava utilization, storage and small-scale processing. Cassava: Biology, Production and Utilization, 281-300.

Wooldridge, J. M. (2002). Econometric analysis of cross section and panel data. Econometric Analysis of Cross Section and Panel Data. MIT Press. Retrieved from https : / / books . google $\cdot$ pt / books ? id = cdBPOJUP4VsC

World Health Organization. (2003). Effectiveness of interventions and programmes promoting fruit and vegetable intake. Geneva, Switzerland. 